\title{
Determination of Blood Age by Morphological Changes of Different White Blood Cells
}

\author{
Hayam Z. Thabet ${ }^{1}$, Nagwa M. Ghandour ${ }^{1}$, Marwa H. Bakr ${ }^{2}$
}

\begin{abstract}
KEYWORDS

Age,

Blood,

White blood cells, $\mathrm{pH}$.
\end{abstract}

\section{Introduction}

It is an important issue for forensic pathologist to determine the time passed since death either for the body as a whole or for some of its tissues and components. Blood has advantage from forensic perspective that it is unaffected by factors such as age, gender, diet, diurnal cycles and stress, so it is ideal for postmortem interval (PMI) determinations. Estimation of the age of a bloodstain can be particularly useful when bloodstains are the

\footnotetext{
${ }^{(1)}$ Forensic Medicine and Clinical Toxicology Department Faculty of Medicine - Assiut University, Egypt.

${ }^{(2)}$ Histology Department Faculty of Medicine - Assiut University, Egypt.
}

only piece of evidence available (Donaldson and Lamont, 2013 a).

Many methods have been used for determination of the age of bloodstains. Physiological techniques, changes in enzyme activities and the surface absorption spectrum of bloodstains have been utilized (Fujita et al., 2005).

Blood is a fluid that normally consists of $45 \%$ erythrocytes, $54 \%$ plasma and $1 \%$ leukocytes and platelets. Numerous cells in blood shows varying degree of postmortem changes and these occurring cellular changes could be utilized to estimate death interval (Marieb et al., 1998).

White blood cells (WBCs) are divided into five main types, due to their difference in 
structure: neutrophils $(60-70 \%)$, lymphocytes (20-25\%), monocytes (5\%), eosinophils $(2-4 \%)$ and basophils (0.5\%) (Kumar et al., 2014). Irreversible changes that occur in the WBCs in the internal environment may be due to nonavailability of oxygen, accumulation of carbon dioxide, $\mathrm{pH}$ change and accumulation of toxic products (Bardale and Dixit, 2007).

Blood $\mathrm{pH}$ ranges from 7.35 to 7.45 , and it is one of the most regulated systems in the body. Acid-base buffers such as carbonic acid and bicarbonate ion regulate blood $\mathrm{pH}$ through the respiratory system and the kidneys. After death, the body buffering system is not maintained and blood $\mathrm{pH}$ changes can occur (Cotran et al., 1994).

The aim of the study was to monitor in vitro morphological changes of white blood cells that occur with time from (0-60 hours), as indicators for age of the blood sample, and to correlate these changes with blood $\mathrm{pH}$ levels in relation to time pass.

\section{Material And Methods}

\section{Morphological study}

Ten milliliters $\left(\begin{array}{ll}10 & \mathrm{ml}\end{array}\right)$ blood was withdrawn from the cubital vein of 20 apparently healthy human volunteers after consent using wide bore plastic syringe. Samples were put immediately in glass tubes containing $0.2 \mathrm{ml}$ of $10 \%$ ethylene diamine tetra acetic acid (EDTA) solution as anticoagulant (Bardale et al., 2010). Exclusion criteria's were: known blood diseases or general diseases (hypertension, diabetes or infection) and history of previous blood transfusion. The experiment took place in March with atmospheric temperature varied from $26^{\circ} \mathrm{C}$ at day to $12{ }^{\circ} \mathrm{C}$ at night.

Samples were left in room temperature. At times (0, 6, 12, 24, 48 and 60 hours), a drop of blood from each sample was spread on a glass slide and left to dry then stained with Hematoxylin and Eosin (H\&E) for light microscope examination. The nuclear and cytoplasmic morphological changes in white blood cells i.e. neutrophils; lymphocytes, monocytes and eosinophils had been recorded in Histology Department, Faculty of Medicine, Assiut University.

\section{pH level estimation}

At times $(0,6,12,24,48$ and 60 hours), mixing of the sample was done and $1 \mathrm{ml}$ of the sample was taken and put into a clean tube, centrifuged at 2500 round per minute (rpm) for 15 minutes. Plasma $\mathrm{pH}$ level was measured by $\mathrm{pH}$ meter (Analyticon Biotechnologies AGD35104 Lichtenfeis, made in Germany). $\mathrm{pH}$ meter calibrated each time of use with $\mathrm{pH} 4.0$, 7.0, and 10.0 calibrators.

\section{Ethical considerations}

This research was approved by The Research Ethics Committee of the Faculty of Medicine-Assiut University (Ref code: 17300062). Informed consent was taken from all individuals who participated in the study. Confidentiality of the data was guaranteed.

\section{Statistical Analysis:}

All analyses were performed with the IBM Statistical Package for Social Sciences (SPSS) program version 20.0 software. One way ANOVA test was used to determine whether there are any statistically significant differences between the means of $\mathrm{pH}$ levels at different time intervals. $P$ value $<0.05$ was considered significant. 


\section{Results}

\section{Morphological changes of white blood cells}

Due to the low percent of basophils $(0.5 \%$ of total white blood cells), their detection in blood film was rare so, the study of their morphological changes with time was difficult. After 60 hours the nature and type of the cells (except lymphocytes) could not be identified, so further estimation was meaningless.

Neutrophils: they constitute $(60-70 \%)$ of the total white blood cells. At zero time, mature neutrophils had segmented nucleus with 2 to 5 lobes joined by a thin filament. The cytoplasm of a mature neutrophil was pink or nearly colorless and possesses moderate granules (Figure 1). At 6 hours, the cells appeared similar to zero time but with darker stained nucleus (Figure 2). At 12 hours and at 24 hours, the cells appeared with pyknotic nucleus (irreversible condensation of chromatin in the nucleus of a cell) (Figure 3) and pyknotic irregular shape nucleus (Figure 4), respectively. At 48 hours, the cells appeared with irregular degenerated nucleus (Figure 5). At 60 hours, the cells appeared with irregular swollen nucleus (Figure 6).

Lymphocytes: they constitute (20-25\%) of total white blood cells. At zero time, mature lymphocytes had spherical nucleus, and scanty pale blue cytoplasm (Figure 1). At 6 hours (Figure 2) and at 12 hours (Figure 3), the cells appeared normal. At 24 hours (Figure 4), at 48 hours (Figure 5) and at 60 hours (Figure 6), the cells appeared with pyknotic irregular shaped nucleus.

Monocytes: they constitute (5\%) of total white blood cells. At zero time, mature monocytes had kidney-shaped nucleus (Figure 1). At 6 hours, the cells appeared similar to zero time but with darker stained nucleus (Figure 2). At 12 hours, the cells appeared with cytoplasmic and nuclear vacuolation (Figure $3)$. At 24 hours, the cells appeared with degenerated nucleus (Figure 4). At 48 hours, the cells appeared with irregular degenerated nucleus (Figure 5). At 60 hours, the cells appeared degenerated with pyknotic irregular shaped nucleus (Figure 6).

Eosinophils: they constitute (2-4\%) of total white blood cells. At zero time, mature eosinophils appeared with bilobed nucleus and coarse cytoplasmic granules (Figure 1). At 6 hours, the cells appeared similar to zero time but with darker stained nucleus (Figure 2). At 12 hours, the cells appeared with eccentric nucleus (Figure 3). At 24 hours, the cells appeared with swollen vacuolated eccentric nucleus (Figure 4). At 48 hours, the cells appeared with nuclear degeneration (Figure 5). At 60 hours, the cells appeared degenerated with eccentric pyknotic nucleus (Figure 6). 

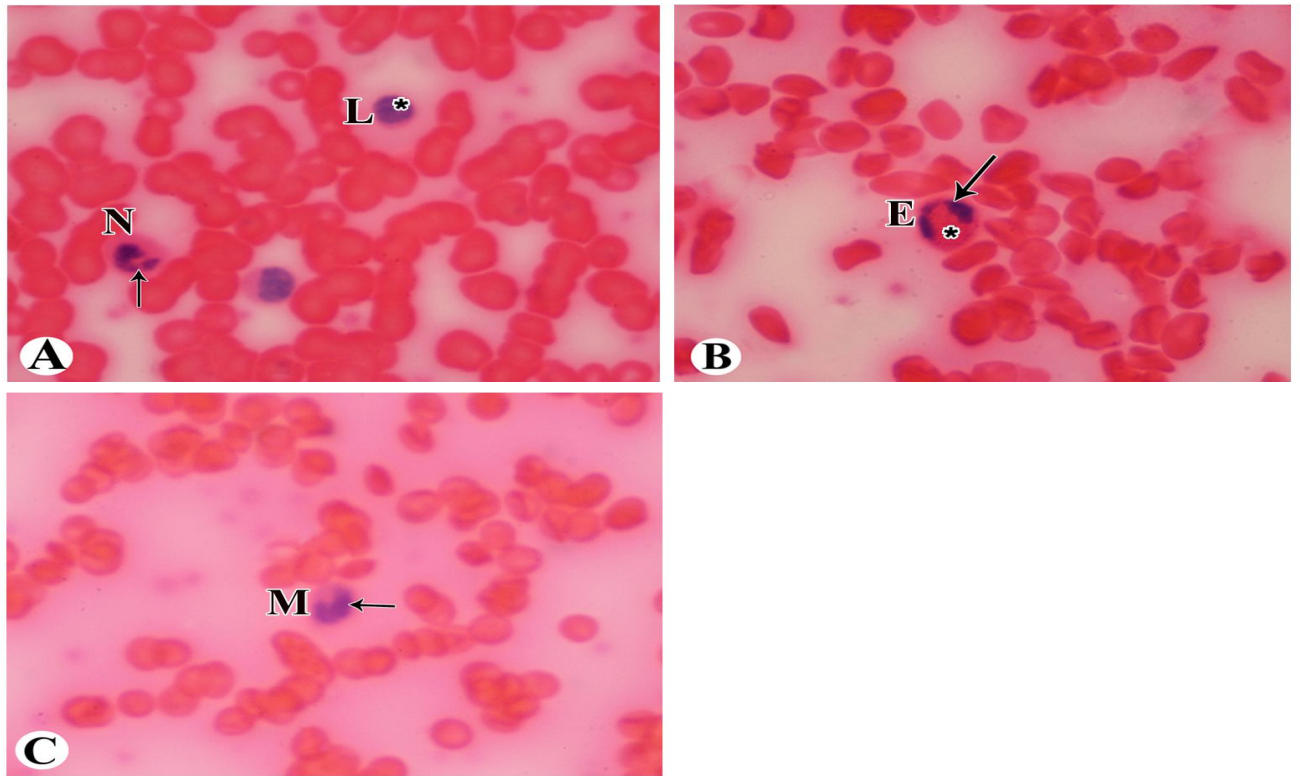

Fig. (1): A photomicrograph of peripheral blood films showing normal morphological appearance of white blood cells at 0 hour; (A) Neutrophil (N) appear with multilobal nucleus (arrow) and lymphocyte (L) with spherical nucleus (*) (B) Eosinophil (E) with bilobed nucleus (arrow) and coarse cytoplasmic granules $(*)(\mathrm{C})$ Monocyte $(\mathrm{M})$ with kidney-shaped nucleus (arrow) (H\&E x1000).
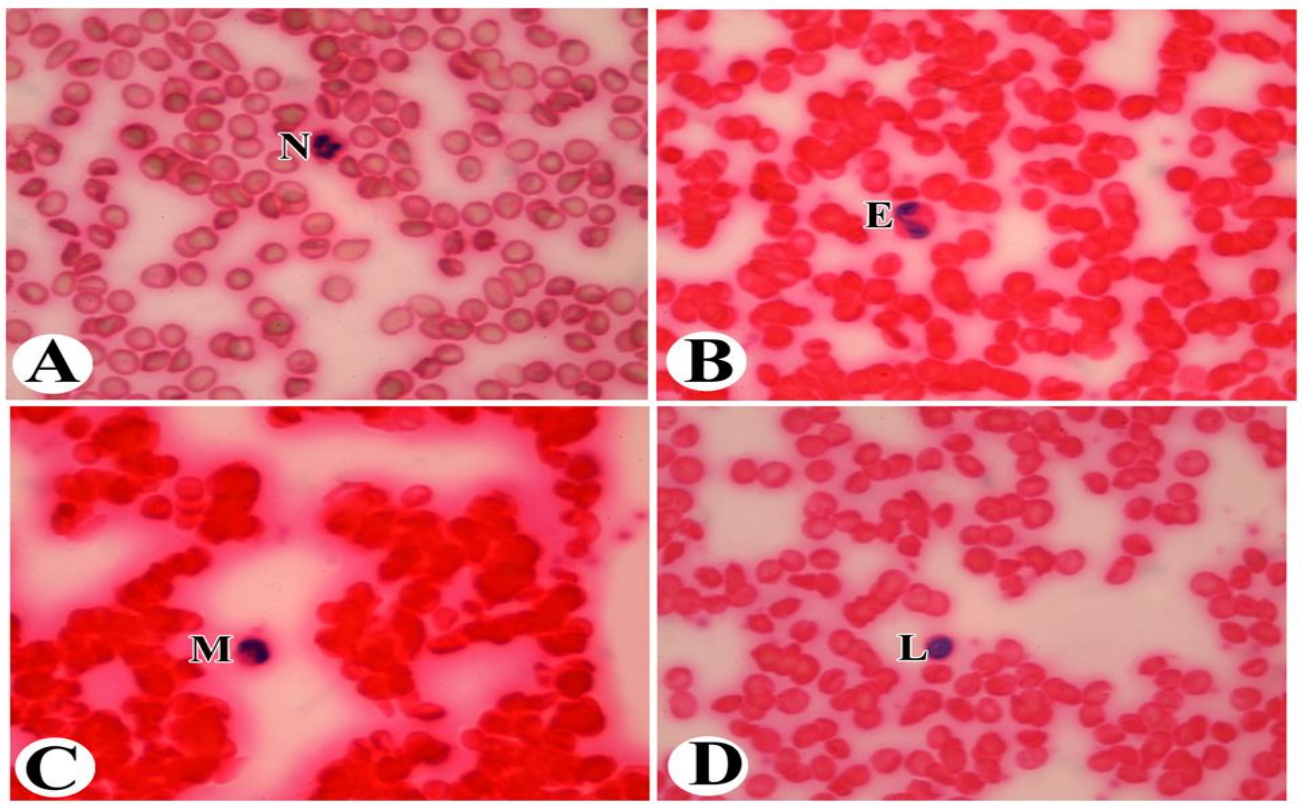

Fig. (2): A photomicrograph of peripheral blood films showing morphological changes of white blood cells at 6 hours; (A) Neutrophil (N) (B) Eosinophil (E) (C) Monocyte (M) (D) Lymphocyte (L). The cells appeared similar to zero time but with darker stained nucleus (H\&E X 1000). 

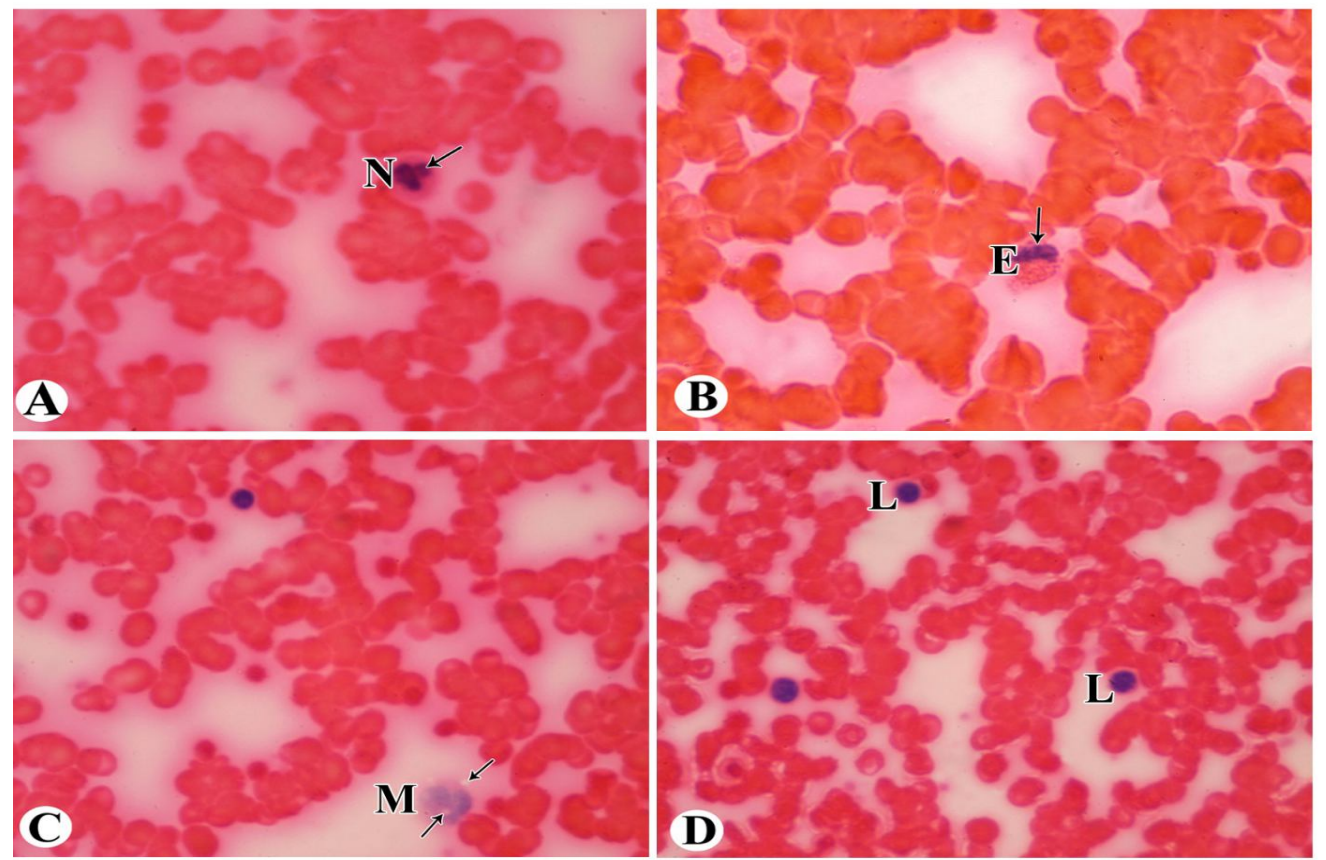

Fig. (3): A photomicrograph of peripheral blood films showing morphological changes of white blood cells at 12 hours; (A) Neutrophil $(\mathrm{N})$ with pyknotic nucleus (arrow) (B) Eosinophil (E) with eccentric nucleus (arrow) (C) Monocyte (M) with cytoplasmic and nuclear vacuolation (arrow) (D) Lymphocytes (L) with normal appearance (H\&E x1000).

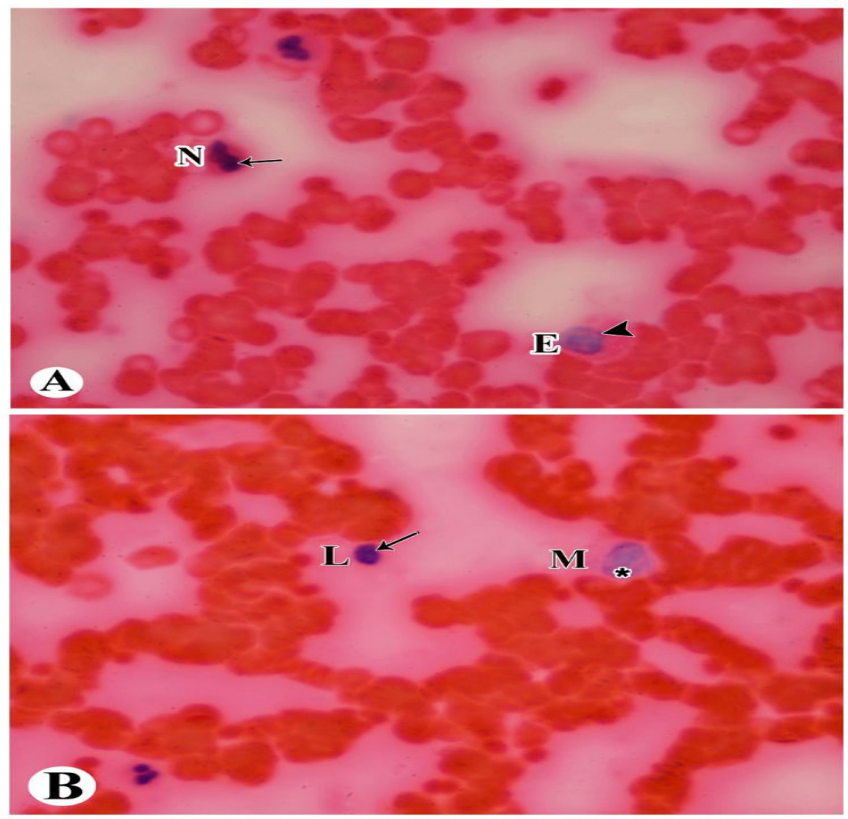

Fig. (4): A photomicrograph of peripheral blood films showing morphological changes of white blood cells at 24 hours; (A) Neutrophil (N) with pyknotic irregular shaped nucleus (arrow) and Eosinophil (E) with swollen vacuolated eccentric nucleus $(\boldsymbol{\Delta})(\mathrm{B})$ Monocyte $(\mathrm{M})$ with degenerated nucleus $\left(^{*}\right)$ and lymphocyte (L) with irregular pyknotic nucleus (arrow) (H\&E X 1000). 

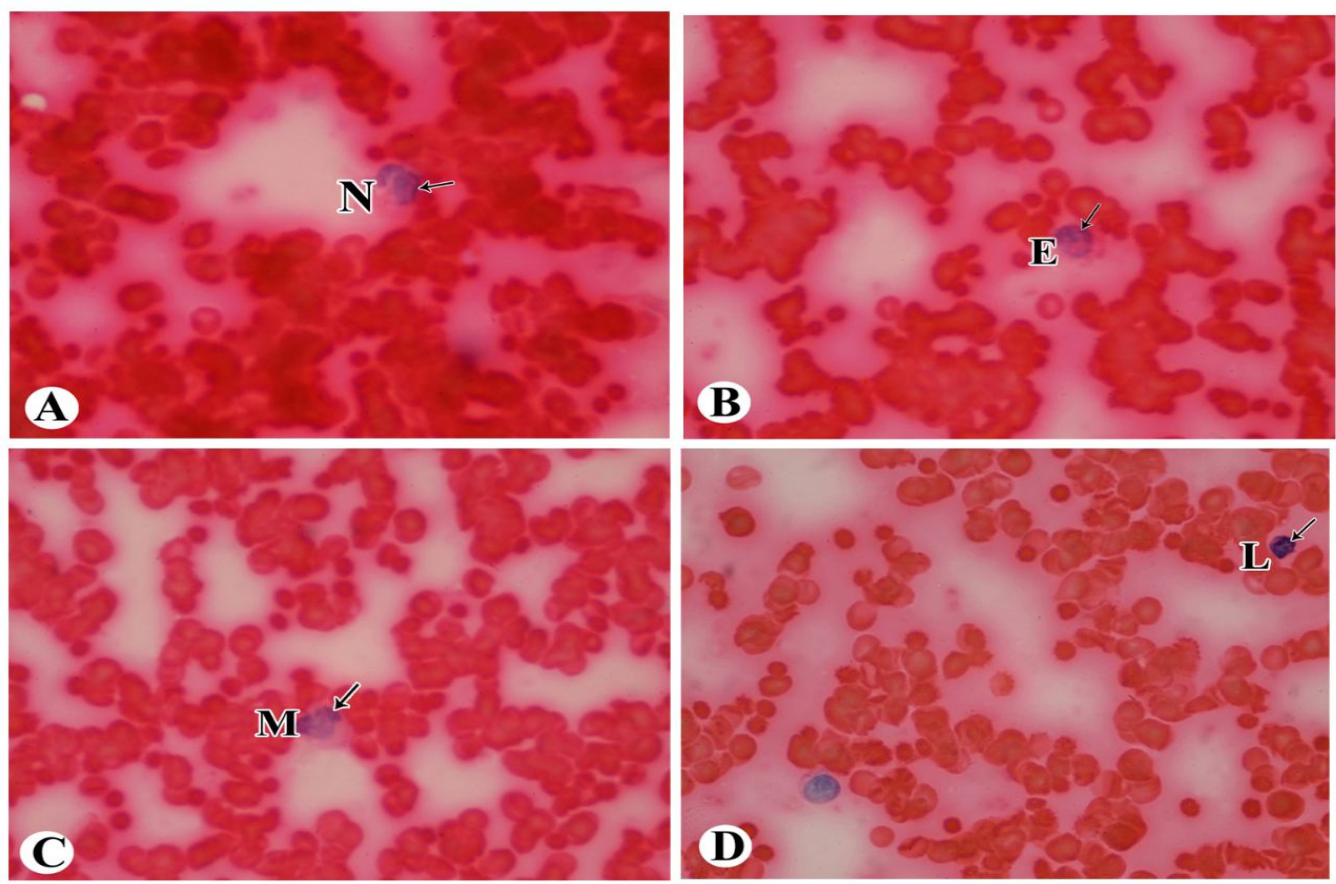

Fig. (5): A photomicrograph of peripheral blood films showing morphological changes of white blood cells at 48 hours; (A) Neutrophil (N) with irregular degenerated nucleus (arrow) (B) Eosinophil (E) with nuclear degeneration (arrow) (C) Monocyte (M) with irregular degenerated nucleus (arrow) (D) Lymphocyte (L) with irregular pyknotic nucleus (arrow) (H\&E X 1000).
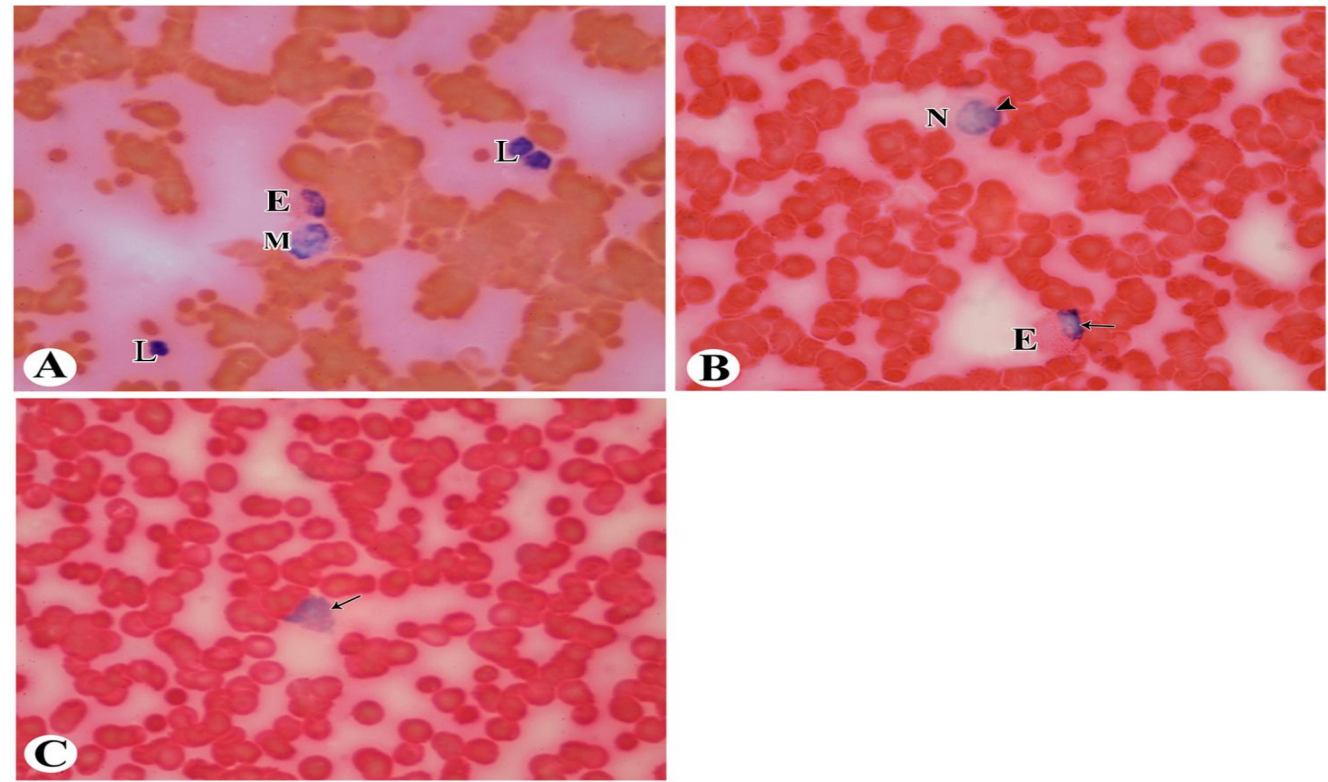

Fig. (6): A photomicrograph of peripheral blood films showing morphological changes of white blood cells at 60 hours; (A) Degenerated monocyte (M), eosinophil (E) and lymphocytes (L) with irregular pyknotic nuclei (B) eosinophil (E) with eccentric pyknotic nucleus (arrow) and neutrophil $(\mathrm{N})$ with irregular swollen nucleus ( $\mathbf{\Delta}$ ) (C) Degenerated leukocyte (arrow) (H\&E X 1000). 


\section{pH level estimation:}

The $\mathrm{pH}$ level for samples at different time intervals was measured and results were expressed in mean \pm SD as shown in table (1) and figure (7). There was significant difference $(\mathrm{p}<0.05)$ between $\mathrm{pH}$ level at zero time $(7.273 \pm 0.021)$ and $\mathrm{pH}$ level at 6 hours $(7 \pm 0.057)$. There was significant difference $(\mathrm{p}<0.01)$ between $\mathrm{pH}$ at zero time and $\mathrm{pH}$ at 12 hours $(6.9 \pm 1)$. There was highly significant difference $(\mathrm{p}<0.001)$ between $\mathrm{pH}$ level at zero time and its level at 24 hours $(6.85 \pm 0.03)$, at 48 hours $(6.35 \pm 0.02)$ and at 60 hours $(6.167 \pm 0.03)$ respectively as shown in table (2).

Table (1): $\mathrm{pH}$ levels (presented as mean \pm SD) at different time intervals

\begin{tabular}{|c|c|c|c|c|c|c|}
\hline $\begin{array}{c}\text { Time } \\
\text { (Hours) }\end{array}$ & At zero time & At $\mathbf{6 ~ h}$ & At $\mathbf{1 2}$ h & At $\mathbf{2 4}$ h & At $\mathbf{4 8 ~ h}$ & At $\mathbf{6 0 ~ h}$ \\
\hline $\mathbf{p H}$ & $7.273 \pm 0.021$ & $7 \pm 0.057$ & $6.9 \pm 1$ & $6.85 \pm 0.03$ & $6.35 \pm 0.02$ & $6.167 \pm 0.03$ \\
\hline
\end{tabular}

SD: Standard Deviation

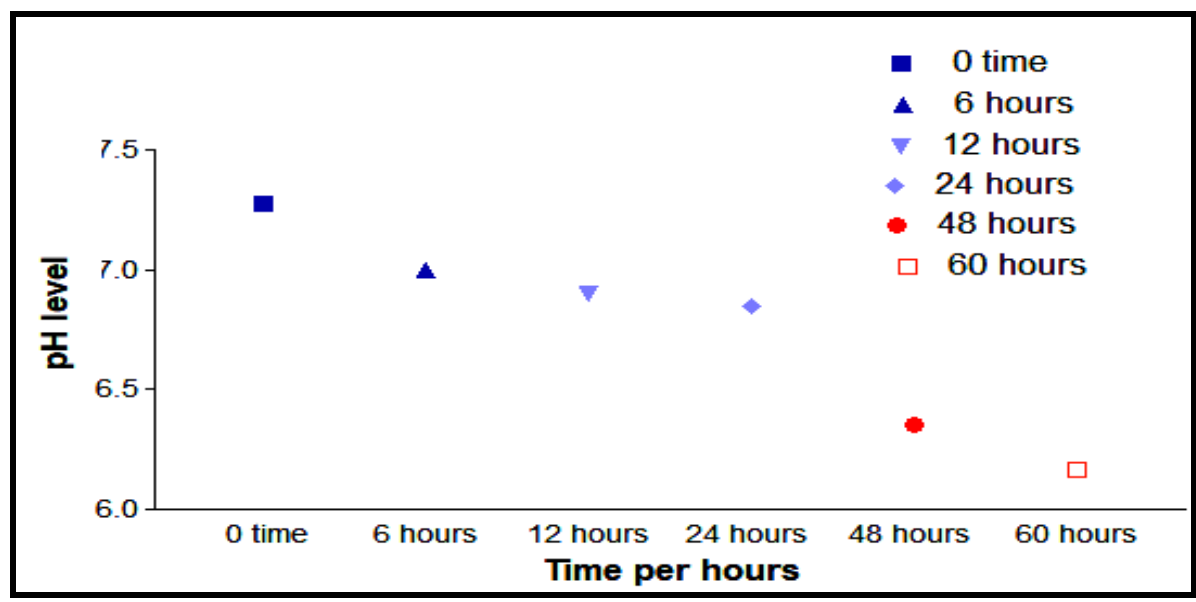

Fig. (7): $\mathrm{pH}$ levels (presented as mean $\pm \mathrm{SD}$ ) at different time intervals

Table (2): Comparison between the means of $\mathrm{pH}$ levels at different time intervals.

\begin{tabular}{|c|c|c|c|c|c|}
\hline & At zero time & At $\mathbf{6 ~ h}$ & At 12 h & At 24 h & At 48 h \\
\hline At 6 h & $\mathrm{p}=0.0114^{*}$ & & & & \\
\hline At 12 h & $\mathrm{p}=0.0038^{*}$ & $\mathrm{p}=0.2879$ & & & \\
\hline At 24 h & $\mathrm{p}=0.0003^{*}$ & $\mathrm{p}=0.0808$ & $\mathrm{p}=0.4818$ & & \\
\hline At 48 h & $\mathrm{p}<0.0001^{*}$ & $\mathrm{p}=0.0005^{*}$ & $\mathrm{p}=0.001^{*}$ & $\mathrm{p}=0.0003^{*}$ & \\
\hline At 60 h & $\mathrm{p}<0.0001^{*}$ & $\mathrm{p}=0.0002^{*}$ & $\mathrm{p}=0.0004^{*}$ & $\mathrm{p}=0.0001^{*}$ & $\mathrm{p}=0.0142^{*}$ \\
\hline
\end{tabular}

\footnotetext{
* Significant.
} 


\section{Discussion}

As other tissue cells, blood cells lose their normal morphology as a result of postmortem autolysis and putrefaction until they are unidentifiable. The changing process through normal morphology to unidentification period can be a useful criterion for estimating postmortem interval (Henssge and Madea, 2004).

It is recommended to use untreated whole blood to study blood samples, in vitro, for simulation of blood at crime scenes as realistic as possible. But, without adding anticoagulant blood will clot within 30 seconds, so anticoagulants are used to prevent early clotting. Many anticoagulants exist for preventing in vitro blood coagulation, including heparin, citrate, and EDTA. However, no evidence is reported in the literature for the influencing of the anticoagulants on the processes associated with ageing of bloodstains (Bremmer et al., 2012).

In the current study, the morphological changes of different white blood cells that occur with time pass from (0-60 hours), as indicators for age of in vitro blood sample, were studied using light microscope after staining with H\&E. The results showed that lymphocytes were the most resistant cell for morphological changes with time. They appeared normal after 12 hours and changes began to be obvious after 24 hours in the form of pyknotic degenerated irregular shaped nucleus.

In agreement of the present study the results of (Penttilä and Laiho, 1981) who reported that lymphocytes were more resistant to autolysis than the other types of white blood cells. But they stated that normal stained lymphocytes were seen in up to 270 hours postmortem.
Also, in agreement with this, Dokgöz et al. (2001) detected similar morphological changes of white blood cells, on their examination of blood smears from blood samples taken from non-refrigerated cadavers (for 21 hours postmortem) and hospital patients (for 120 hours total storage time). They reported that the degenerative changes of lymphocytes started at 24 hours in both groups. Also, their results confirmed that anticoagulants have no influence on the processes associated with ageing of white blood cells of bloodstains. In the current study, morphological changes of neutrophils, monocytes and eosinophils appeared after 12 hours in the form of pyknotic nucleus, irregular swollen nucleus, degenerated nucleus, as well as, cytoplasmic and nuclear vacuolation .

Also Dokgöz et al. (2001) noticed the same changes in the form of pyknosis, cytoplasmic and nuclear vacuolation, and degeneration of nucleus but started at 6 hours.

In the present study, the nature and type of the cells (except lymphocytes) could not be identified after 60 hours. In controversy to these results, Dokgöz et al. (2001) reported that degenerated neutrophils were unidentifiable beyond $96 \mathrm{~h}$ in vitro, while eosinophils and monocytes were unidentifiable beyond $72 \mathrm{~h}$ after in vitro storage. Lymphocytes were still identifiable beyond $120 \mathrm{~h}$ and later. This longer period than the present study may be explained by other factors mainly the room temperature $\left(24{ }^{\circ} \mathrm{C}\right)$ and type of stain (May-Grunwald stain, followed by Giemsa stain) used by them.

Also, in disagreement with the present results, Bardale and Dixit (2007) reported that degenerative changes were early identified in monocytes and eosinophils (4-6 hours), intermediate in neutrophils (5-15 hours) and late in lymphocytes (25-27 hours). The morphology of any cell beyond 30-hour PMI was not identifiable. 
As well as, Babapulle and Jayasudera (1993), noticed that identifiable eosinophils and monocytes were first to 'disappear' (by 60 hours), followed by neutrophils (by 66 hours), and finally identifiable lymphocytes disappeared completely at or around 84 hours from the time of death.

Laiho and Penttilä (1981) reported that well-preserved neutrophils and monocytes were seen in the peripheral blood after over 200 hours, from cadavers with known PMI .

The use of post-mortem biochemistry is now a standard practice along with conventional, physical methods to determine the PMI (Vass et al., 2002). The ante-mortem blood $\mathrm{pH}$ is regulated to stay within the narrow range of 7.35 to 7.45 (Sawyer et al., 1988).

This morphological change could be explained by the change of the surrounding media of WBCs which, on the current study, was the change of $\mathrm{pH}$ of blood from normal to acidic (less than 7) with pass of time. The results of the current study showed that $\mathrm{pH}$ level of the in vitro blood sample was significantly decreased with pass of time.

Poloz and O'Day (2011) explained this by the fact that death results in global anoxia, after blood circulation ceases, and thereby cells cannot produce energy in the form of ATP. As energy production stops, cells die and cell membrane permeability is changed in. Once membrane permeability is compromised, breakdown of cellular homeostasis occur and ions and other molecules flow in and out uncontrollably.

While, Donaldson and Lamont (2013 b) reported that the $\mathrm{pH}$ of human blood stored in a tube decreased very slightly compared to ante mortem levels going from 7.4 to 7.1 over 96 hours. They stated that, in vitro blood in a tube has no glucose store to supply fuel for anaerobic metabolism; consequently no significant lactate accumulation occurs to help lower blood $\mathrm{pH}$. But, in vivo, the rapid decrease in blood $\mathrm{pH}$ is most likely due to the accumulation of metabolites and ions such as bicarbonate, carbon dioxide, hydrogen ions, dihydrogen phosphate ions, and lactic acid building up in a corpse due to autolysis.

Coe (1993) previously found that $\mathrm{pH}$ level changed from 7.0 to 5.5 by 20 hours postmortem in cardiac blood taken directly from 11 individual human remains. This change in in vivo blood $\mathrm{pH}$ may occur due to accumulation of acidic metabolites. Lactic acid is produced by lactate dehydrogenase from pyruvate via anaerobic glycolysis in skeletal muscle, liver and red blood cells when oxygen is insufficient.

However, Thibodeau and Patton (2007) reported that autolysis does not occur in erythrocytes because they do not have lysosomes so, acidic cellular metabolites such as carbon dioxide, hydrogen ions, formic acid and lactic acid generated inside cells are not released rapidly from lysing cells to significantly lower $\mathrm{pH}$ as would occur in a corpse .

\section{Conclusion}

The results showed that lymphocytes were the most resistant cell for morphological changes with time. Changes in lymphocytes were detected after 24 hours in the form of pyknosis and degeneration of the nucleus. Morphological changes of neutrophils, monocytes and eosinophils were detected at 12 hours in the form of pyknotic nucleus, irregular swollen nucleus, degenerated nucleus and cytoplasmic and nuclear vacuolation. After 60 hours the nature and type of the cells (except lymphocytes) could not be identified. The morphology of white blood cells and $\mathrm{pH}$ level of in vitro blood sample could be used as indicators for the age of the blood. 


\section{References}

Babapulle, C.J. and Jayasundera, N.P. (1993): "Cellular changes and time since death". Med. Sci. Law, 33(3):213-222.

Bardale, R. and Dixit, P.G. (2007): "Evaluation of morphological changes in blood cells of human cadaver for the estimation of postmortem interval". Medicolegal Upd., 7 (2): 35 39.

Bardale, R.; Dixit, P.G.; Gharpure, A.G. Tumram, N.K. and Ali, M. (2010): "Utility of blood smear and bone marrow smear examination in autopsy practice: A preliminary observation". I.I.J.F.M.T., 8(3):115-121.

Bremmer, R.H.; de Bruin, K.G.; van Gemert, M.J.; van Leeuwen T.G. and Aalders, M.C. (2012): "Forensic quest for age determination of bloodstains". Forensic Sci. Int., 216(13): $1-11$.

Coe, J.I. (1993): "Postmortem chemistry update; Emphasis on forensic application". Am. J. Forensic Med. Path., 14(2):91-117.

Cotran, R.S.; Kumar, V. and Robbins, S.L. (1994): Cellular injury and cellular death. In: FJ Schoen. Robbins Pathologic Basis of Disease, $5^{\text {th }}$ ed. Philadelphia: W.B. Saunders Company. P.P. 4-11.

Dokgöz, H.; Arican, N.; Elmas, I. and Fincanci, S.K. (2001): "Comparison of morphological changes in white blood cells after death and in vitro storage of blood for the estimation of postmortem interval". Forensic Sci. Int., 124 (1):25-31.
Donaldson, A.E. and Lamont, I.L. (2013a): "Estimation of postmortem interval using biochemical markers". Australian Journal of Forensic Sci., 46(1):1-19.

Donaldson, A.E. and Lamont, I.L. (2013b): "Biochemistry changes that occur after death: potential markers for determining post-mortem interval". PLoS ONE., 8(11): e82011.

Fujita, Y.; Tsuchiya, K.; Abe, S. et al. (2005): "Estimation of the age of human bloodstains by electron paramagnetic resonance spectroscopy: Long-term controlled experiment on the effects of environmental factors". Forensic Sci. Int., 152(1):39-43.

Henssge, C. and Madea, B. (2004): "Estimation of the time since death in the early post-mortem period". Forensic Sci. Int., 144(2-3):167-175.

Kumar, B.; Mahto, T.; Kumari, V. and Kumar, A. (2014): "Determination of time since death from changes in morphology of white blood cells in Ranchi, Jharkhand". J. Indian Acad. Forensic Med., 36(2): 184-187.

Laiho, K. and Penttilä, A. (1981): "Autolytic changes in blood cells and other tissue cells of human cadavers I. Viability and ion studies". Forensic Sci. Int., 17(2):109-120.

Marieb, E.N.; Tonini, C. and Martin, T. (1998): Human Anatomy and Physiology. $4^{\text {th }}$ ed. Menlo Park, California; Harlow: Benjamin/ Cummings Science. P.P. 15-25.

Penttilä, A. and Laiho, K. (1981): "Autolytic changes in blood cells of human cadavers. II. Morphological studies". Forensic Sci. Int., 17(2):121-132.

Poloz, Y. and O'Day, D.H. (2011): The use of protein markers for the estimation of the 
postmortem interval. In: Forensic Pathology Reviews, Volume (6), Chapter (14), Turk (ed.). P.P. 277-294. Available at:

https://www.researchgate.net/publicati on/225921135. Accessed January 15, 2018.

Sawyer, W.R.; Steup, D.R.; Martin, B.S. and Forney, R.B. (1988): "Cardiac blood $\mathrm{pH}$ as a possible indicator of postmortem interval'. J. Forensic Sci., 33:1439- 1444 .
Thibodeau, G.A. and Patton, K.T. (2007): Fluid and electrolyte balance. In: Anatomy and Physiology, $6^{\text {th }}$ edition, Missouri: St Louis Mosby. P.P. 10671087.

Vass, A.A.; Barshick, S.A.; Sega, G. et al., (2002): "Decomposition chemistry of human remains: a new methodology for determining the postmortem interval". J. Forensic Sci., 47(3):542-553. 


\title{
تحديد عمر الدم بواسطة التغيرات الشكلية لخلايا الدم البيضاي المختلفة
}

\author{
هيام زكريا ثابت'، نجوى محمود غندور' ، مروة حسن بكر'

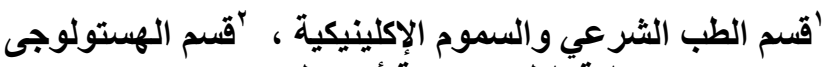

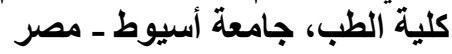

تحديد عمر الدم هو موضوع مهم في مجال الطب الثرعي. وقد أجريت هذه الدر اسـة لتوضيح التغيرات

الثكلية التي تحدث في خلايا الدم البيضاء مع مرور الوقت وربطها مـع تغيير مستوى الرقم الهيدروجيني للام المخزن خارجيا:: تم عمل فيلم للام مصبوغ بالهيماتوكسلين والأيوسين وتحديد مستوي الرقم الهيدروجيني في وهي

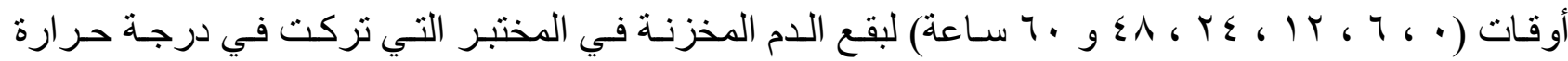

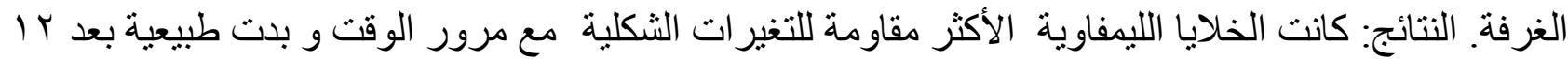

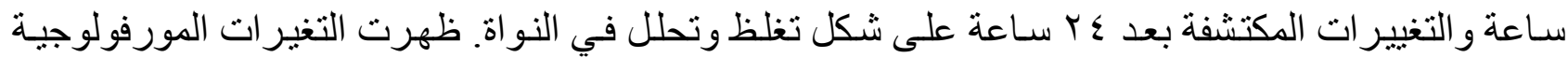

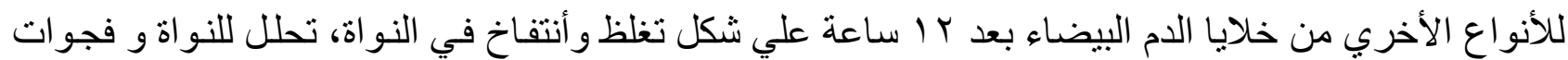

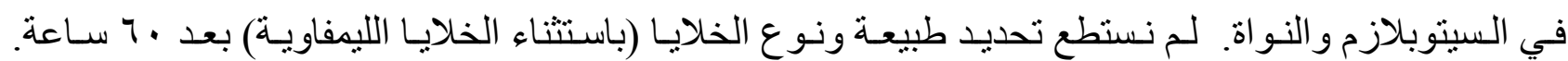
وكذلك كان هنالك تغير في مستوى الرقم الهيدروجيني متو افق مسع التغير ات الثكلية لخلايـا الدم البيضاء. كان

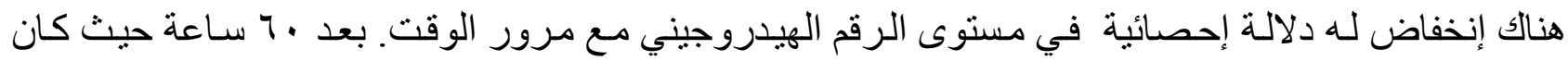

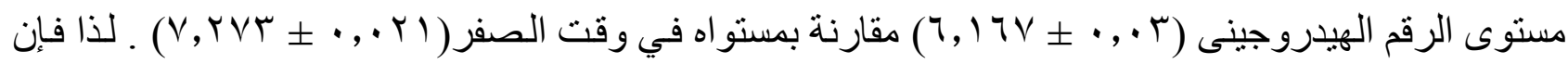
مورفولوجيا خلايا الدم البيضاء ومستوى الرقم الهيدروجيني لبقع الدم المخزنـة خارجيا يمكن أن يعطي مؤشرا لعمر الدم. 